\title{
Two Ambitious Projects with Different Results
}

\author{
Boris A. Binkin
}

Cand. Sci. (Econ.), Honoured economist of the Russian Federation, Economic analyst for Boston Almanac "Lebed", USA

boris.binkin@mail.ru

\begin{abstract}
This article is devoted to the history of the oil and gas industry in Western Siberia. This research aims at a comparative analysis of the means and results of implementing two ambitious projects of regional development in different socioeconomic and political contexts. The author considers the model for, and factors in developing the West-Siberian oil and gas industry in comparison with the execution of the American Tennessee River Valley development project (the US government's Tennessee Valley Authority programme). They appear to be quite similar on a number of levels. The author points out that the West Siberian Oil and Gas Complex (WSOGC) programme was formed purely as a resource base for forced extraction of oil and gas, followed by their transportation beyond the boundaries of the Tyumen Region. Thus, as the latter turned into a kind of "raw materials appendage", the interests of the local population were given little consideration. In contrast, the TVA programme has become a regional programme aimed at improving the economy and living standards of stagnant territory encompassing seven US states. The author reveals the impact of political and administrative factors on the specifics of these programmes' implementation. The author states that the proposals of some Siberian and Tyumen researchers to create a programme approach to the WSOGC and the Tyumen Region in light of the experience of the TVA were justified. Yet, these ideas were rejected by the state bodies both of the USSR and the Russian Federation. The author concludes that the most significant social needs of the Tyumen Region in the oil and gas industry development were ignored. This tendency continues to a certain extent nowadays.
\end{abstract}

Keywords: West-Siberian oil and gas industry, US government's TVA programme, management of territory's social development, region.

DOI: $10.21684 / 2587-8484-2017-1-1-27-38$

"I am not stupid enough to believe that the market alone will solve all social problems. Inequality, unemployment and pollution cannot be overcome without the active participation of the state".

Joseph Stiglitz [5],

Nobel Prize winner in Economics

\section{INTRODUCTION.}

\section{TENNESSEE AS AN ORGANISATIONAL HOMOLOGUE OF THE WSOGC}

Let us first point out some salient parallels between the two largest projects of their kind in the world:
Citation: Binkin B. A. 2017. "Two Ambitious Projects with Different Results". Siberian Socium, vol. 1, no 1, pp. 27-38. DOI: $10.21684 / 2587-8484-2017-1-1-27-38$

the development of the Tennessee River Valley (the US government's TVA programme) and the creation of the West-Siberian oil and gas complex (WSOGC) in the Soviet Union on the territory of the Tyumen Region. They deserve special consideration and study. Both countries, the USA and the USSR, at different stages of their history for various reasons faced a severe crisis. The symptoms of the crisis were similar: firstly, the paralysis of the social reproduction mechanism, and, secondly, the aspiration to restart the stalling engines of the countries' economies.

The TVA programme managed to cure the "ailing" area, whereas in Western Siberia the local govern- 
ment, departments and agencies thoroughly robbed these lands, causing local ecosystems to be largely destroyed. First geologists, then oil and gas companies in the early 1960 s came to unspoiled places in Siberia, where small indigenous ethnic and Russian population groups lived relatively well, according to their standards. The principal population group in the area became a unique category, which the research refers to as "flow population". It soon engulfed the indigenous population, including the peoples of the North.

The TVA programme's main objective remained the same for more than 83 years. The programme strived to bring about as much good for as many people as possible, including those yet to be born. "The TVA programme is similar to the Soviet plans", stated one Congress member. The President's reaction to this was ironic: "You can call the TVA programme either fish or meat, but it is surprisingly tasty for the Tennessee Valley's residents" [2]. The Soviet plan, as far as we know, had no financial wisdom, dividend interest or other subtleties of the kind. The state itself, at the expense of its budget, financed the programme through ministries, formed TIC (territorial industrial complexes) and accounted for its own activity. The Americans took full advantage of their property rights and updated their programme at least four times, bringing it closer and closer to people's needs. The West-Siberian project, devoid of the slightest possibility for tactical manoeuvering, existed, as cybernetics aptly puts it, in a "brainless cat mode" (i.e. "a cat is fed only to maintain its vitality in a half-dormant state").

At the same time, the American experience is quite eloquent. According to the law, only the US President had the right to develop the TVA programme plans. However, Roosevelt promptly delegated this function to the TVA Corporation. Was he burdened by too much power? Did he lack ambition? Hardly. The president was simply aware that the power of a country and the prosperity of a nation do not depend on the clarity of its ideology, but on the efficiency of its economy. From the outset and without any pressure from above, the TVA connected production, social, and environmental goals. In the Soviet version, social plans were annually updated, and detailed down to each and every seating place in public baths. Unlike the Soviet ministry and state command system, the long-term behaviour of the TVA in the region was aimed at resolving local problems not in place of, but together with the American state authorities. The indirect impact of the Corporation on the territory was substantial. Above all, it led to cheap electricity, flood protection, and the fundamental improvement of river transport. These factors of production infrastructure made the TVA attractive for energy and high technology enterprises and transnational corporations.

The TVA's attention to the region and potential partners is the essence of the programme's main lesson. If the government invests in a territory, it is usually done to create favourable basic conditions for the self-development of business and the whole area. Direct government investment in extractive industries is not usually implemented.

Initially, the means of financing the project and the interaction between the TVA and various federal agencies were established. The history of regional planning in the United States is indebted to a study of the experience of State plans in the Soviet Union. The assistant to the US Minister for Agriculture, Guy Tugwell, visited the USSR in 1927 and became acquainted with the scientific planning of the national economy. "The future is becoming visible in Russia", he wrote. He sincerely believed that "the free market is also an anarchic one, generating an inconsistent, hopeless confusion of conflicting goals and objectives" [7]. He considered that the free market should be replaced by national planning, implying certain rules on the part of technicians and managers. National planning leads to an integrated economy, and, as a result, society is free from wild and hungry individualism.

\section{THE WSOGC - A WORLD MEGAPROJECT}

The West-Siberian oil province is rightfully called the global innovation of the $20^{\text {th }}$ century. Amid the taiga, tundra, bogs and almost deserted land, oil and gas fields were developed over a relatively short period of time. About 20 cities and 25 regional centres were founded, and thousands of kilometres of pipelines, roads and power lines were laid. There has never been another project of such magnitude, 
carried out in such extreme conditions and such short time. Tyumen hydrocarbon deposits defined the long-term development strategy of not only Western Siberia, but also of the entire country. The establishment of the main oil and gas framework of the USSR involved more than $1.5 \mathrm{mln}$ people. "Establishing the WSOGC is one of the greatest feats of the Soviet people, judging by the scope of work, the number of people involved, and the flame of physical and moral strength" [4: 169].

The combination of extreme natural and socioeconomic factors specific to the northern territories has a negative impact on the human constitution. Winters are long and cold, with strong winds. There are long polar nights, a lack of natural light, and ultraviolet radiation over large areas. There are bogs, permafrost, and an absence of sustainable agriculture. All these factors disrupt normal physiology, making it difficult for newcomers to adapt. The formation of a new mining region in the Western Siberia started with the Government Decision of December $4^{\text {th }}, 1963$. Hence, some oil-producing companies and construction organisations were established, launching the construction of a number of oil and gas pipelines.

As a result, in 1977 gas production in Western Siberia became as significant as oil production. New gas field development took place, as did the transition from fountain to mechanised oil production. This was accompanied by innovations in urban planning, involving resources from other republics of the USSR. The West Siberian oil and gas region made Russia one of the major energy superpowers. The leading role in the control system of the complex belonged to the USSR's Presidium of the Council of Ministers and the WSOGC State Planning Commission (West Siberian Interdepartmental Territorial Commission).

Of course, the oil and gas industry in the USSR and the development of oil and gas in the Tyumen Region were influenced by international factors. During this period, the price of oil was becoming an increasingly essential element of foreign policy. The increased oil and gas needs in European industry, the growth of global oil and gas consumption, and the increase in world prices for these raw materials enabled the USSR to strengthen its political and economic influence in the international arena. The increase in energy exports was the most important tool in this change. All these facts led to the active development of oil and gas in Western Siberia, although there was no general policy document on WSOG in the $1960 \mathrm{~s}, 1970$ s or 1980 s.

Ministries and departments working in this industry, along with Party instructions, were driving the WSOGC. A systematic approach in document preparation was not practiced. There were no set standards on work or document submission. Organisations' balance sheets were issued separately by each individual unit and subsequently dissolved in the activities of sectorial structures. Such policy management could not but lead to serious problems, such as in the fields of petrochemicals and refining. The largest number of decisions on social development in the region date from the 1980s, when the focus was on the expansion of new towns and villages. This could but require the creation of an efficient construction industry.

By 1989 oil production in Western Siberia increased 1,864.9 times compared to 1964, with an increase in oil production in the country of $250 \%$. The share of Western Siberia in the USSR's oil production in the late 1980 s was $65 \%$. The share of the Tyumen Region in Western Siberian oil production amounted to $98.8 \%$. Gas production within the WSOGC in 1966-1989 increased 967 times, while the Soviet Union's production increased 5.7 times. The entire volume of WSOGC natural gas was extracted on the territory of the Tyumen Region. The proportion of gas production in the WSOGC, compared to Soviet Union gas production in the late 1980s, was 66.4\%" [3: 92].

However, the development of industrial infrastructure during this period was in a state of constant catch-up in relation to the extracting industries. Energy and construction potential lagged behind the needs of the oil and gas complex. Industrial infrastructure in the areas of gas production was weak, as from the beginning, reliable sources of energy were not established in the region. A regular rail service appeared only at the end of the 1980s [6].

We can assume that the second stage in WSOGC development, as part of the Soviet era, started in 
1989 with the transition to the market economy. At that time important administrative structures within the WSOGC were eliminated, industrial associations gained independence, and some joint ventures were created.

In the initial period, the development policy of the Tyumen fields focused on single deposits only. The basic principle of oil extraction was the oil fountain, i.e. there was maximum extraction at minimum cost. It was believed that oil must be taken quickly and withdrawn from the inhospitable territories, thereby reducing the cost of social infrastructure. Thus, over time the environment of Western Siberia was impacted by water pollution from oil spills, brine spills along the pipeline, the pollution of forest cover, etc.

1991 was a turning point in the WSOGC's development history. Oil production in 1990 decreased by almost $40 \mathrm{mln}$ tons to $552.4 \mathrm{mln}$, and in 1991 it fell by $90 \mathrm{mln}$ tons. The government cast the oil and gas industry adrift. A key moment in the history of modern Russia came in the 1990s. To a large extent it was linked to the collapse of the WSOGC, a unique cluster of oil and gas on the territory of the Tyumen Region. Blitz privatisation of the WSOGC undermined the resource base for sustainable development of the Russian state and contributed to the disintegration of the Tyumen Region into three subjects of the Russian Federation.

\section{THE TVA PROGRAMME, THE WSOGC AND THE ENVIRONMENT}

As a result of implementing the TVA programme in the USA, a method of using federal resources to ensure a solution to local problems was worked out, and the opportunity to provide technical assistance to targeted areas appeared. To analyse the interaction of the TVA programme with the external environment, three specific classes of external factors can be examined: federal agencies, local authorities (from the municipality to the state) and business. These factors ended up in peaceful coexistence on equal basis, with a shift in emphasis from initial confrontation to healthy competition and the organisation of joint business. The US is a large and diverse country, and its central government has often suffered from limited knowledge of local conditions. It is significant that in a capitalist state, the centralised bureaucratic government in their development programmes gained the potential for enforcing decisions in a decentralised environment with extensive use of local staff and institutions. The ideas of power decentralisation contained a new social and political landscape, created by a combination of science and technology.

In the case of the WSOGC, interaction initially occurred with several other environmental factors and diametrically opposed results. There was no private business, local authorities of all ranks were weak and mainly served as a screen for the exercise of real power functions by the Party hierarchy. Party bodies understood their role in two ways. Firstly, maximum mobilisation of all resources for the rapid extraction of oil and gas from the depths, and their transportation according to the tasks of the planned economy policy makers. Secondly, imperative selfpreservation of the system and power structure through authoritarian methods of management, indoctrination-based economic management and the appointment of personnel convenient to the Party apparatus. The main actors in the WSOGC were allied ministries, structured as state monopolies. Oil companies, gas companies, power engineering and construction did not account accurately for wasted money and did not have serious scientific capital.

From the start, the WSOGC programme was stateplanned and organised as a combination of controlled departmental programmes. Strong bureaucracy prevented the West-Siberian Interdepartmental Territorial Commission from transforming into an effective body and blocked all initial attempts to intervene in its affairs and plans. As a result, the WSOGC programme was a stand-alone, self-regulating system that existed in the minds of individual scientists, mainly from the Institute for Economics and Industrial Engineering of the Siberian Branch of the USSR Academy of Sciences. The administrative command system, based on sectorial management, crushed and dissolved it functionally and organisationally. This situation continued until the advent of a new direction in management which evolved in the Yeltsin 
period. All strategic decisions were made in Moscow, by the USSR Commission of the Council of Ministers on WSOGC. The programme sectors were managed by agencies.

The similarities and differences between the two programmes allow an overview of their socioeconomic features as integral parts of the social systems which initiated them.

\section{THE TVA TODAY AND TOMORROW}

Meanwhile, the TVA objectives were achieved. The Tennessee River became navigable, floods became rare, and rural electrification was completed. The living standard of the valley population increased and became higher than that of urban residents. New industrial centres were founded. For more than 40 years the population grew, from 4 to $7 \mathrm{mln}$ at the beginning of the 1990s. As a result, TVA became the largest state corporation with 40,000 employees. Engineers and managers who once worked for this company are very highly appreciated in the private sector.

Researchers of the history of the TVA divide it into four periods:

- the new course (1933-1939);

— the Second World War (1939-1946);

- the post-war period (1947-end of 1960s);

— the end of the 1960s-the present.

The first period enjoyed an atmosphere of social innovation, courage and experiment. The debate on the constitutional legitimacy of the TVA's creation continued, with the growing influence of opposition. This initial period was characterised by the local population's distrust as to the very possibility of implementing such an ambitious project. However, as the demand for local labour increased, when tens and even hundreds of thousands of local people found jobs with TVA, their attitude to the project changed from doubt to active support. The construction of six large and many small dams, hydroelectric power plants and energy infrastructure in the 1930s contributed to the development of energy-intensive industries such as, e.g., electrometallurgy and the chemical industry.

World War II marked the beginning of a new stage in the project's development. The abundance of cheap electricity was something of a discovery for the military industry of the time. During the war, the demand for electricity on the part of companies involved in military production increased greatly (Alcoa, du Pont de Nemours, Monsanto Chemical Co., etc.). The aluminum industry of the Tennessee Valley grew significantly due to the aviation industry and other military customers. As a result, the most prominent national production of metal came to be in Alcoa. The $2^{\text {nd }}$ centre for the aluminum industry in the Tennessee Valley was Listerhill in Alabama. In addition to the aluminum industry in the valley, there appeared other electrometallurgy sectors, such as manganese, ferroalloy, and electric steel production. In 1945, the TVA established a plant for the production of phosphate fertilizers in the town of Godwin, Tennessee, near phosphorite deposits. During the war, this plant produced elemental phosphorus for military purposes. A factory in Muscle Shoals became the main supplier of phosphorus during the war. In 1943 and 1944, the production of calcium carbide (a raw material for a number of branches of organic synthesis and for the production of synthetic rubber) began. The presence of synthetic ammonia plants, phosphorus, aluminum powder and wastes from numerous ginneries was the impetus for the emergence of local ammunition factories, necessary for America's war effort. During this period the mountainous part of the state of Tennessee (a remote and deserted place near the Clinton area on the River Clinch, a tributary of the Tennessee not far from Norris hydroelectric station) became the place for nuclear laboratories and plants. The complex was constructed over an area of about $240 \mathrm{~km}^{2}$, subsequently named "Oak Ridge Reservation". By the end of the war Oakridge city, founded in the north-eastern part of the reservation, had turned into the largest centre for nuclear weapons production.

The end of World War II marked the beginning of the $3^{\text {rd }}$ period in the history of the TVA. The transformation of the military industry along the "path of peace" increased the TVA's attractiveness as an important factor in the creation of new energyintensive industries in the region. When the water 
resources of the basin were exhausted, the TVA switched to the construction of thermal power plants. The TVA programme itself was increasingly becoming an electric grid system with the primary purpose of electricity production. A further increase in TVA facilities came with the development of nuclear energy. In 1995, a license for the construction of two Watts Bar nuclear power plants with a capacity of $2.4 \mathrm{mln} \mathrm{kV}$ was granted. Agriculture is another essential element in the development of the TVA economy. Nowadays there are more than 82,000 farms, $59 \%$ of which specialise in cattle breeding. West Tennessee is extremely fertile, with deep black soil; its main products are corn and cotton. Central Tennessee yields abundant harvests of tobacco. East Tennessee is famous for winter wheat, and rich pastures contribute to cattle breeding (much cattle is exported). In the east of the valley, there are many pine trees, in the west there is cypress, larch, virgin poplar, and almost everywhere there is tulip tree, hickory, magnolia, walnut, pecan tree, maple, ash and different kinds of oaks. In central Tennessee there are vast forests of red cedar. The timber industry has become an important branch of the state's industry. Tennessee is one of the leaders in phosphate ore and building stone production, the most valuable variety of which is marble. It contains the $2^{\text {nd }}$ largest zinc mining zone and rich coal, silver and copper reserves. Tennessee industrial products comprise chemical fertilizers, plastics, fabrics, clothing, refrigeration systems, heating appliances and audio-visual equipment. Major corporations with headquarters in Tennessee include FedEx Corporation, Autozone and International Paper Incorporated, based in Memphis; the experimental Corporation and Royal Entertainment Group, based in Knoxville; the Eastman Chemical Company in Kingsport, the North American Nissan headquarters in Franklin; Track Finance headquarters (the Finance division of a well-known mining company) in Nashville, and a new plant owned by Volkswagen in Chattanooga. By the end of the 1970s, the TVA's leaders had focused on experiments in the field of alternative energy sources such as solar energy.

\section{THE WSOGC AND THE TYUMEN REGION: PRESENT AND FUTURE}

Russia is now experiencing a systemic crisis affecting its quality of life. Areas that have oil and gas resources, such as the Khanty-Mansiysk and YamaloNenets Autonomous Okrugs and the Tyumen Region, which receive tax revenue under an agreement among territories, live a little better. However, the problems of the once-uniform Tyumen Region cannot be compared to those of any other Russian region. This fact is important both for setting goals and understanding the future of the region and the country as a whole. This area should be compared with similar global enclaves: the US Tennessee programme, the development of Texas and Houston, or Norway and the United Arab Emirates. Globally, it is considered that natural resources belong not to individuals or companies but to the society as a whole, and the future of a country depends on their reasonable exploitation.

In Canada, e.g., taxation rates are specific to different areas and range from 10 to $45 \%$. Calculations have shown that by levying $14 \%$ of the profits of Tyumen hydrocarbon sale since 1965 and spending only half of these funds on portfolio investment in objects beyond its borders, the region, since 1993, could have accrued $\$ 50-60$ bln annually. The common social programs of the districts and the south of the region include housing and utility provision, resettlement of surplus population, consumption of standard basic products, healthcare, education and training, culture, tourism and ecology. According to the calculations of Tyumen researchers, these cost about $\$ 40 \mathrm{bln}$. Annual contributions to the "Fund for descendants" would have financed all these social programs, and there would have been resources left for investment. Unfortunately, the "Fund..." has not appeared in the region [1:171]. For next to nothing and without legal registration, various groups of businessmen managed to capture the unique natural resources worth hundreds of billions of dollars belonging to the indigenous peoples of the North, the existing residents of the region, and the Russian state as a whole. Today, the Russian budget is actually formed by the resource duties paid by companies located on the territory of the once-uniform Tyumen 
Region and by resource duties levied on the territory by the federal centre, with the transfer of artificiallygenerated metropolitan status to Moscow and St. Petersburg.

The Tyumen Region faced a unique precedent. When Federal districts were created in Russia, the Tyumen Region, the Khanty-Mansiysk Autonomous Okrug and the Yamalo-Nenets Autonomous Okrug were attributed to the Urals Federal District. These quite artful and unreasonable state structures emerged under the formerly uniform West-Siberian complex, allowing the looting of unique oil and gas deposits with the approval and support of the state and centralisation of the federal budget.

Centralisation of power through the federal budget was soon a trap for the state itself. National centralisation facilitated the centralisation of RF subjects' budgets, burying the level of local government, and thereby causing a loss of contact between the authorities and the Russian people. The accommodation of indigenous people of the Tyumen Region and the small peoples of the North was based on unsound foundations. It depended, critically, on the Federal Centre. At this crucial moment, the majority of the Tyumen Region's population was made up of people of different beliefs and attitudes, not tied to the roots of the territory. Therefore, many were unable to understand the cause-and-effect relationships of the events. Yet, the rent payment, as a basic income, is still being reduced, thus causing the final process of financial losses for this resource not to be far away. The Tyumen Region is unstable in terms of its territories' revenues and the artificial transfer of oil and gas complex control centres to Moscow. Meanwhile, the problems related to the future of the region are aggravated by the following:

- the territory was deprived of minerals tax;

- income tax for oil and gas companies is reduced and depends on personal arrangements with the heads of oil and gas companies;

- the districts' population is increasing unreasonably, which will become a serious problem in the near future. There is an unreasonable migration process, with a rise in crime and an overloading of public facilities and infrastructure;
- major environmental measures are needed;

- there is an increased necessity to enhance oil and gas processing capacity, but, given the monopoly of large companies on these products, the development of this area is difficult;

- there is no uniform chain for the production and marketing of agricultural products within the region, making it uncompetitive for all participants;

- a uniform chain to improve the efficiency of the social and cultural spheres, tourism and sports based on a general programme of regional development is required.

This is not a definitive list of the issues that will permanently affect the development of the Tyumen Region, the Khanty-Mansiysk and the Yamalo-Nenets Autonomous Okrugs.

\section{DIFFERENT RESULTS}

It is striking that Siberia seems to be a symmetrical complement to Canada and the United States. They are like parallelograms on the two sides of the Pacific triangle. They are characterized by the same climate zones and the same surface and subsoil riches. Yet, why are these two giant pages of a torn book so different from each other? Siberia is similar to the USA, though not completely. The fate of countries that have a deep continental position depends on their coastline and rivers as a means of transportation. Siberia has little coastline, and its rich rivers flow into the Arctic Ocean. If Siberia could be turned horizontally on a 90 degree axis, and the Urals covered it from the North... Yet modern Siberia has no natural connection with the world. To sell goods, it is necessary to accumulate goods; to accumulate goods, it is necessary to sell goods; to sell goods, it is necessary to export goods, and in order to export we need means of transportation. What can Siberia do here? The TransSiberian railway, which was constructed before the Revolution using foreign loans, revealed the value of transportation for the region. After the completion of the railway, Siberia's economy turned to face the global market. As L. Trotsky, one of the leaders of the 1917 Revolution, put it, "Setting Siberia on the Soviet track does not mean breaking global relation- 
ships and dependencies with on-going economic opportunities. For Siberia it means, firstly, the export of countless Siberian raw materials and the necessity to be on the global market, to overcome its inferior position. During the coming years, and during the years of industrialisation for Siberia, that means, first of all, the cleaning, sorting and primary processing of raw materials to make resources more portable, so that they may become more profitable to transport and may encourage buyers to purchase resources from Siberia. In the absence of local capital, major industrialisation of Siberia will happen only with the growth of exports, which means: if industrialisation happens only in the transportation sphere - roads, highways, railways, canals - other industries, including heavy industry, should initially grow as subsidiaries in relation to these objectives of the Siberian economy" [6].

In the case of the WSOGC, goal-setting was carried out by the Centre through a system of decisions: the West-Siberian oil and gas complex was initiated as a fuel and energy base in the East of the country. However, the approach was far from that of a TPC (territorial production complex), with its ideas of crosssectorial unity and correlation in production planning, capital construction, logistics, working and living conditions, geological and organisational measures. A paradox results from this marked difference: the TVA, understood as a local authority, managed to implement regional policy in the Tennessee valley. This policy relied on the goals and methods of the TPC approach. In contrast, the Soviet sector managers showed that TPC ideas could not be implemented by industrialists, with their basic training and sectorial thinking. The best achievements of the departments within the WSOGC can be regarded as a more or less successful compilation of Western approaches to the development of new territories. These approaches included prefabricated construction of ground facilities and pipeline systems, and shift-based drilling and operation of production wells. For example, in terms of developing the social infrastructure of a hydrocarbon extraction complex, the WSOGC is the opposite of the TVA. In creating the WSOGC, the USSR showed the world that non-integrated exploitation of hydrocarbons in quantities particularly dangerous for future generations may be practiced with minimal investment in infrastructure of all types. This process was simultaneously destroying wildlife, bringing the indigenous peoples of the North to the brink of extinction. All this was done within the framework of "socialism".

Neither the TVA nor TPC approaches could be applied to the WSOGC without modifications. The West Siberian oil and gas programme and the system of achieving its objectives seem unique in terms of volume, spatial dislocation, climatic difficulty, economic and geographical conditions. Spatial localisation during the period of WSOGC's formation was not discussed. Firstly, the Tyumen Region, except for a narrow strip of the Trans-Siberian railway, never had serious industrial potential. Secondly, the deadlines for oil and gas production in massive volumes did not provide for advanced creation of the resource base in the south of the region. That is why, in the first period of the investment programme, until 1975, this base rehearsed a "strategy of expanding cooperation". Only later did supportive construction bases begin to appear around the WSOGC (mainly in the Urals). In the final stage of launching the WSOGC, infrastructure was actively developed in the south of the Tyumen Region.

The Tennessee project was planned as a regional programme aimed at strengthening the economy and improving the living standards of the population of a stagnant territory. The WSOGC programme, in turn, from the outset, was purely resource-based, aimed at forced oil and gas production with subsequent transportation of the resources out of the Tyumen Region. In the case of the TVA, electricity, the main commercial product, was distributed and consumed in the areas of the Tennessee Valley. It formed the foundation for the intensive development of industry, agriculture and regional economy infrastructure. The economy and social life of the residents thus improved, because according to the American Constitution, all citizens have equal rights in all areas. In the case of the Soviet planned economy, with the help of pipeline systems (the most powerful in the world), the "piercing" of an economically non-developed area was followed by the "suction" of high-quality raw materials on a massive scale. The industrial economy of the WSOGC 
thus had minimal contact with the backward economy of the region. Therefore, in the early stages of the project, the Tyumen Region almost did not feel the pulse of self-development, in spite of unprecedented investment in the dynamic oil and gas sectors. This was how an ugly settlement system consisting of ghost towns and shift-work settlements arose according to the standards of faceless oil-robot cities.

The Tennessee valley programme was united by a system of measures to ensure integrated control of the river and its tributaries. This system, inherently environment-regulating, served as a basis for the development of energy and other high-tech industries, as well as of the whole life-supporting infrastructure of the TVA. The structure of the WSOGC was different. In the early stages of its lifecycle (1965-1985), when investments snowballed, stimulated by internal needs and the rise in oil prices (after 1973), civilised approaches to territory development did not exist. Investments in social infrastructure were minimal. The Tyumen-Surgut-Nizhnevartovsk railway, with access to Urengoi and Yamburg, was considered to be the maximum possible extent of production infrastructure. But even in this case, the transportation system was developed according to a sectorial structure, which is less effective for the regional economy. The "lattice" approach is considered to be more progressive. The conditions existed to implement this type of approach, which proved its effectiveness in the West, and especially in America and Canada. The Tyumen Region was open to the West and East by rail: through Sergino and Labytnangi from the West, and through Kolpashevo and Bely Yar from the East.

The most that could be done within the planned economy in the early 1980 s was the following. The USSR State Planning Committee elaborated a Targeted Comprehensive Programme for WSOGC development, providing a gradual and systematic escalation of the oil and gas complex into a TPC. Examining this programme, it is obvious that it was a typical colonial project created by technocrats as a paper screen to conceal the pseudo-scientific activity of various ministries and departments in the Tyumen Region. Besides, no one was going to implement this programme seriously, as the oil and gas complex, with its pragmatic approach, suppressed everything else. Both the TPC and industrial centres were formed spontaneously.

After 1989, futile attempts to boost production in a context of limited geological knowledge on the depletion of old fields and a lack of equipment initiated some changes in the WSOGC's attitudes and approaches. The second phase of economic superstructure began. Then some companies for the primary processing of gas condensate and associated gas were established in the northern regions. Petrochemical programmes were slowly launched. The priority given to so-called national tasks, contributed to the formation of powerful political, scientific, economic and other structures which caused a deep crisis in the economy, nature, and social situation of the Tyumen Region. "Decisive" actions by local councils at all levels were destructive, thus, further sovereignty was disastrous for the economy. The Tyumen Region was not an exception. Local government did not understand that its task was by any means accessible to Soviet structures: to help stabilise the WSOGC and to increase its effectiveness in the transition to the market economy. Councils at all levels, regardless of their power ambitions and autonomous inclinations, were to realise that oil and gas from the WSOGC served as the axis which the whole collapsing Soviet economy was revolving around. Therefore, it was stated that in the near future, regional elected bodies would not have real and direct control of this axis, as the hydrocarbon export revenue from the fuel and energy complex was of paramount importance for the country. Secondly, there was no prospect of decent social development and economic growth in the Tyumen Region with the collapse of the WSOGC. Moreover, if the impending collapse of the WSOGC were not stopped by some decisive measures, the entire ecosystem of the West-Siberian plain, dissected by powerful and potentially malfunctioning oil pipelines, would become a dangerously explosive area not only socially, but also physically. Realising this, and acting indirectly from below, local councils should have primarily established solid, competent and responsible relays for state economic authority within the WSOGC. Only then, 
as the TVA's experience showed, could everything else follow.

The situation was ambivalent. On the one hand, the bankrupt Centre would seek, through any means necessary, to establish control over the WSOGC. Yet, on the other hand, if economic power over the WSOGC were not decentralised and transferred to a capable regional management structure, the collapse of the oil and gas industry and the regional economy would be inevitable. And ecological disaster would be most likely in the future. Councils, as representatives of the population of the Tyumen Region, could assist the stakeholders in resolving this dilemma, and in finding an acceptable compromise.

\section{CONCLUSION}

1. The main objective of the TVA administration, created by the Federal Law and the Decree of the President of the United States Franklin Roosevelt, was to improve quality of life in the depressed areas of seven US states. As a result of the programme, Tennessee has become one of the most important innovation centres in the USA.

2. Tyumen was created in a different social system. The progress objective was set by Regulation № 795 of the Central Committee of the CPSU and the USSR Council of Ministers of 20 August 1985. It encompassed comprehensive development of the oil and gas industry as the basis for oil and gas extraction in the Soviet Union. It was typical of the Soviet system to meet its objectives at any cost. The methods did not take into consideration the population and their needs, the habitat of indigenous peoples and the environment. As a result, the hasty privatisation of the WSOGC during the Yeltsin/ Gaidar/Chubais period in the 1990s distorted the RF government system. Corruption became legitimate in the people's eyes.

3. The TVA was a new American practice of regional development, created under the influence of the USSR's planned economy. Its experience was subsequently used in modernisation programmes offered by the USA to developing countries. As a US worldwide symbol, the programme became a key strategy for their modernisation. Tennessee eventually became a powerful factor for develop- ment and defining social programme planning reform. Basing on TVA ideas, rivers and other natural resources began to be treated as vast untapped sources of potential energy for irrigation, electrification and reception of other goods as part of integrated development projects. The TVA experiment created fertile ground for various countries' development on the basis of US aid and support.

4. The USSR, the founder of the planned economy, from the very beginning did not issue a single programming document on WSOGC management. The methods for achieving objectives and funding projects were based on the sectorial system of economic management typical of the country. It might seem that the so-called liberals from the Gaidar School of Management, who considered themselves consistent supporters of the market economy and liberalism, prepared programmeoriented proposals for reforming the WSOGC. However, they committed a crime, which previous Russian regimes could not afford. A new Russian elite began to take shape, based on methods like robbery or criminal privatisation.

5. Many people in the USA regularly protest against the TVA, as they consider it to be an illegal intrusion of government into the market. Each year steps are taken to convince the Congress and public opinion that the TVA is contrary to the very essence of capitalism, yet detailed public hearings and analysis allow the TVA to remain in operation. The Obama administration, based on the TVA's 2014 annual report, tried to bring Congress to make 2015 the final year of the TVA's operating as a state corporation. Yet, a consultation with the general public and scientists demonstrated the effectiveness of the TVA's activities. We can briefly outline the main argument for the need to preserve the TVA in the future. An integrated approach helps the TVA to optimise the environmental situation, authorities and the goal of economic development. Privatisation would lead to a number of undesirable consequences, including the weakening and breakdown of important economic and administrative interaction. The TVA's initiatives of economic development are closely linked to its river and land management. There is also a direct benefit for market actors from access 
to competitive prices and reliable electricity. The TVA works actively with local and regional energy companies and state and local agencies on economic issues, providing a variety of benefits and services to attract and retain companies that help local communities to take advantage of opportunities for economic growth. The heated discussion on privatising the TVA's components helped to stimulate the company's operation, making some changes necessary, but maintaining its overall capacity to function as an integrated system.

6. Basic rules for subsoil ownership were not legally defined during the economic reform that took place in the time of political instability in Russia in the late 1980s and early 1990s. Privatisation of public objects was the primary activity. The entire Soviet nation was involved in creating the WSOGC, the territory of development belonged to the indigenous peoples of the North. The very decision on privatising the oil and gas complex was taken regardless of the indigenous peoples of the North, the regional and local authorities, labour groups, trade unions, or any public discussion in Parliament and the press. It was a fraud, a crime, the extent of which was unprecedented globally. The WSOGC was criminally privatised without any legal registration. The subsoil and the country's wealth came into the hands of a narrow circle of people. The Tyumen Region was divided into three subjects of the RF and became an essentially subsidised region as part of the Ural Federal District. This operation was not just a devastating blow for the Russian economy, undermining the resource base for sustainable development of the state. With oil and gas duties, the Russian people were deprived of faith in liberal democratic values and justice.

7. Tennessee in its conception has become a regional programme aimed at improving the economy and the living standards of the population in a stagnant area of seven US states. Electricity, as the main com- mercial product of the TVA, was distributed and consumed in different parts of the Tennessee River valley. It formed the foundation for intensive development of industry, agriculture and regional economic infrastructure. Most of the TVA enterprises' headquarters, contributing to regional budgets, are thus still located in cities along the river Tennessee.

8. The WSOGC programme was focused purely on resources, aimed at forced oil and gas production and their subsequent transportation out of the Tyumen Region. At the same time, the WSOGC economy had minimal contact with the backward economy of the region. During the main stages of its existence, the Tyumen Region almost did not feel the urge for selfdevelopment, in spite of the unprecedented volume of investment in the oil and gas industry. The absence of interaction between mining companies and local authorities prevented them from solving many social and economic problems. In Russia's "shock therapy" transition to the market economy, the main headquarters of oil and gas structures were located in Moscow and St. Petersburg, affecting financial relations of the Tyumen Region with the federal budget and the oil and gas monopoly.

9. TVA programmes were created specifically by research teams and were examined at both regional and federal levels. The TVA is still a public company. Its activities are subject to continuous monitoring and research.

10. The WSOGC was developed on the basis of Party and government directives and industry plans. Siberian and Tyumen scientists made proposals of a programme approach to the WSOGC and the Tyumen Region, taking into account the experience of TVA in the field of regional development. These were rejected both by the USSR and the RF state bodies.

Undoubtedly, the TVA programme and the creation of the WSOGC require additional study and comprehension for the benefit of the entire global community. 


\section{REFERENCES}

1. Binkin B. A. 2014. Klyuchevoy moment [The Key Moment]. Kurgan: Zaural'e.

2. Binkin B. A., Ognev I. 1991. "Regional'nye programmy v SShA i SSSR" [Regional Programmes in the United States and the Soviet Union]. Izvestiya, June 15-16.

3. Koleva G. Yu. 2007. "Zapadno-sibirskiy neftegazovyy kompleks: istoriya stanovleniya i razvitiya (1960-1980-e gg.)" [History of the Development of the West Siberian Oil and Gas Complex (1960s-1980s)]. Vestnik Tomskogo gosudarstvennogo universiteta, no 302, pp. 90-95.

4. Slavkina M. V., Grayfer V. I. 2009. Vremya ne zhdet [Time Does Not Wait]. Moscow: Tsentr.

5. Stiglitz J. 2003. Globalizatsiya: trevozhnye tendentsii [Globalisation and Its Discontents]. Moscow: Mysl'.

6. Trotskiy L. D. 1990. O Sibiri. Rech' na vechere sibiryakov, 28 fevralya 1927 g. v Novosibirske [On Siberia. A Speech at an Evening Meeting of Siberians, 28 February 1927 in Novosibirsk]. Moscow: Nauka.

7. Tugwell G. 1932. "Discussion of Proposals for the Introduction of National Economic Planning". American Economic Review. 